DOI: http://dx.doi.org/10.22483/2177-5796.2018v20n2p327-339

\title{
The poetic-prophetic dimension of Freirean pedagogy to imagine another world possible
}

\author{
Débora Barbosa Agra Junker
}

\begin{abstract}
One of the important but often neglected aspects of reading Freire's work concerns his vision of the human being and the world deeply inspired and validated by his Christian faith. Although this dimension, for the most part, is not explicitly elaborated in his writings, a closer reading may reveal an interesting relationship between Freire's work and the Christian prophetic tradition. This article attempts to contextualize the religious dimension of Freire's social and educational philosophy. In addition, it proposes the poetic-prophetic dimension of the Freirian educational practice as a paradigm to face the challenges we are collectively experiencing in our world today.
\end{abstract}

Keywords: Paulo Freire. Spirituality. Christian faith. Poetic-Prophetic paradigm. Liberation education. Critical pedagogy.

\section{A dimensão poética-profética da Pedagogia Freiriana para imaginar outro mundo possível}

Resumo: Um dos aspectos importantes, mas muitas vezes negligenciados, da leitura do trabalho de Freire diz respeito à sua visão do ser humano e do mundo profundamente inspirada e validada por sua fé cristã. Embora essa dimensão, na maioria das vezes, não seja explicitamente elaborada em seus escritos, uma leitura mais cuidadosa pode revelar uma interessante relação entre a obra de Freire e a tradição profética cristã. Este artigo busca contextualizar essa dimensão religiosa da filosofia social e educacional de Freire. Além disso, propõe a dimensão poético-profética da prática educativa freiriana como paradigma para enfrentar os desafios que estamos vivenciando coletivamente no mundo atual.

Palavras-Chave: Paulo Freire. Espiritualidade. Fé cristã. Paradigma poético-profético. Educação liberadora. Pedagogia crítica 
JUNKER, Débora Barbosa Agra. The poetic-prophetic dimension of Freirean pedagogy to imagine another world possible.

At a time when we seem to walk backwards in the political, social, economic, ecological, and religious dimensions of life, and when, across the globe, the empire-building impetus continues to intensify its violence against racial-ethnic minorities, its greed, and self-centered interested we are tempted to surrender our bodies and minds to its cruel maneuvers. In the midst of such dismay, however, we long for sources that can bring us hope in the task of resisting injustice, contesting the assaults to democracy, and the sequestration of human rights. Looking for inspiration in the work of Paulo Freire and the Christian prophetic tradition, this text aims to draw attention to the poetic-prophetic dimension of Freire's educational praxis as a paradigm to address the current contradictory moment we are collectively experiencing.

The pedagogy of Paulo Freire captures our imagination by revealing and offering us this irrefutable characteristic of what I am calling the poetic-prophetic dimension of Freire's praxis. Such aspect has the power to ignite parts of our beings - other than cognitive - connecting our hearts, hopes, feelings, and imagination to envision what is not yet here, but can come into existence. This distinctive approach has inspired and influenced educators of many frontiers and different languages whether they are members of remote rural villages or representatives of prestigious universities; whether they are from large urban centers or farthest corners of Latin America and Africa.

In imagining and articulating these educational principles, the goal is to challenge the religious discourse to become publicly accountable to Christian values that sustain rather than weaken, a democratic ethos. For more than five decades, Freire's educational praxis has inspired us to enter this struggle "molhados de nossa história," and be conscious of our presence in the world. Our history, even though silenced in many aspects, cannot be erased no matter how strongly the evil supremacies work to co-opt those impressionable individuals in our societies. Freire recognizes that our task as critical educators-involved in the construction of another world possible — can not be accomplished in isolation, but instead needs to be part of a communal effort in the struggle for agency, justice, and democracy.

As it will be articulated throughout this essay, Freire's pedagogy resembles the conception of education found in the Bible through the teachings of Jesus. Jesus' pedagogy is revealed in the confrontation with oppressing forces of the Roman Empire, in facing social injustices, in challenging religious legalism, and in overcoming cultural prejudices. Jesus is the embodiment of a resilient being. In his life, he encountered countless situations of pain, 
JUNKER, Débora Barbosa Agra. The poetic-prophetic dimension of Freirean pedagogy to imagine another world possible.

marginalization, and injustices. His commitment to meet the needs of "the least of these" was embodied in his attitudes, in his words, and in his deeds. Resistance in Jesus' life could be translated as subversive because in such a context of material, religious, and ethical deprivation, he offered alternative ways of imagining and being in this world that were in direct contrast with the established order. He fed the hungry; he healed the sick; he showed acts of justice and compassion toward the needy. He also rebuked those who despised and oppressed the poor. Therefore, this essay proposes that these principles found in the biblical narrative are present, in some ways, in the intricacies of Freire's pedagogy: a pedagogy that respects the experiences of learners, recognizes the socio-cultural reality where they belong, and trusts in their capacity to learn and overcome their oppressive situation. This poetic-prophetic dimension of Freire's work is what I will examine next.

\section{Words and Images to Co(i)nspire}

The gifts of compassion, critical discernment, and creative imagination make poets and prophets extraordinary people endowed with grace-filled spirit that allows them to experience life in transcendental ways. Poets are not afraid to venture out of the orthodox demands of language, using metaphors and evocative descriptions to elucidate how the realities of their existence are recorded and processed through their bodies, experiences, and memories. This almost irreverent ability to see beyond what is apparent to the eye allows the poet to open new horizons and to cross different passages of consciousness subtly illuminating what goes unnoticed for most people. In savoring the events and experiences of daily life through their aesthetic sensibility, poets touch the souls of those who read or hear their most profound utterances.

Poets, through their evocative work, sometimes undress, unmask, and open forbidden recesses of our souls so that we can see more clearly the things not so apparent to the naked eye. Other times, they use coded words to protect what has been revealed to them. Furthermore, amid pain and heartbreak, poets provide us new 'eyes' to see and new 'images' to interpret reality.

The eyes of poets are de-institutionalized, unchained, and undomesticated. Therefore, unfettered by conventions, orthodoxy, and institutional demands, they remain outside the Chronos, free of structural bonds and able to imagine, to dream, and to hope. Like exquisite cooks who prepare their dishes combining, experimenting, and balancing different flavors, colors, 
JUNKER, Débora Barbosa Agra. The poetic-prophetic dimension of Freirean pedagogy to imagine another world possible.

fragrances, and textures, poets offer us metaphors and images that are meant to be appreciated with gusto. By presenting the possibilities of seeing reality anew, poets have the power to animate our imaginations so that we can conjure up new modes of flourishing in the world.

Prophets, on the other hand, are dissonant voices who do not feel intimidated by the hegemonic power and who are eager to employ their acute capacity to interpret their sociocultural context towards the reparation of precarious life conditions. Equipped with the sensitivity of the poets to see and feel the pain of the people, they denounce the abuses of oppressive and unjust structures affecting the more vulnerable in society. And yet, prophets not only rebuke but also announce what needs to be done to improve the living conditions for all, calling everyone to an urgent conversion of the heart. According to Rabbi Abraham Heschel, "what poets recognize as poetic inspiration, the prophets call it divine revelation, and like a poet, they are endowed with sensibility, enthusiasm, and tenderness, and, above all, with a way of thinking imaginatively" (HESCHEL, 1962, p. 147-148). Prophecy is, thus, the product of poetic imagination.

Compelled by the commitment to present an alternative interpretation of reality, the task of the prophet is to help those who have been persuaded to accept their suffering-and the oppression to which they are subjected to believe as destiny-to gain a critical consciousness of their reality. Recognizing what is false, dehumanizing, manipulative and unjust is part of the prophet's duty. As Walter Brueggemann puts it, the work of the prophet "is nothing less than an assault on the consciousness of the empire, aimed at nothing less than the dismantling of the empire both in its social practices and its mythic pretensions" (BRUEGGEMANN, 2001, p. 9) The task of the prophet is, therefore, twofold, "not only as a censurer and accuser but also as a defender and consoler" who brings the world into a divine focus (HESCHEL, 1962, p. 24). The prophet's gift is a gift of discernment, of being simultaneously aware of the 'word' and 'the world', one of Freire's fundamental premises.

The above account elucidates an important dimension of the work of the prophet: that she is not merely a person who harshly confronts power structures and unethical actions that subjugate people. Rather, she claims her agency so as to dialectically sustain her critical worldview while also preserving the sensitivity of a poet. In the Christian tradition, prophets are portrayed as the spokespersons of God. They are paradoxical people whose words can concurrently bring judgment, hope, distress, and comfort. 
JUNKER, Débora Barbosa Agra. The poetic-prophetic dimension of Freirean pedagogy to imagine another world possible.

Holding in creative tension the active imagination of the poet and the profound vision of the prophet should be not only virtues to be desired but abilities to be sought after so that endurance, justice, and solidarity can emerge.

\section{Through the Eyes of the PrOphET}

Considering the characteristics of poets and prophets indicated above, some parallels will be highlighted concerning the poetic-prophetic movements of Freire's life and work. Freire's work exposes these characteristics in a very remarkable way. Throughout his writings, it is possible to identify the richness of his chosen words to express his ideas in a very enchanting way. As a poet, he plays with words, and as a prophet he reveals their meanings. His poetic prose so beautifully rendered in Portuguese - and not adequately captured in the English translations because the language structure and not because of the inability of his translators - are significantly in harmony with the poet's talent of carefully choosing the words and the prophet's ability to claim their ultimate significance. The PrOphET (intentionally written to show how the abilities of poet and prophet are intrinsically intertwined) beautifully articulates words that invoke and provoke changes.

In, for example, Pedagogia da Esperança (FREIRE, 1994), many of these expressions and images embellish the text. Readers aptly perceive the many terms that substantiate his poetic depiction of ideas, which have been engraved in our minds in remarkable ways. Freire provides us new 'eyes' to see and new 'images' to ponder alternative ways to interpret reality through undomesticated means. Some of the expressions ${ }^{1}$ employed in this book are:

\footnotetext{
Algumas dessas tramas terminaram por me trazer ao exilio a que chego com o corpo molhado de história, de marcas culturais, de lembranças, de sentimentos, de dúvidas, de sonhos rasgados, mas não desfeitos, [...]” (p. 12).

Some of these threads have brought me to the exile to which I come with a soul drenched in history, with cultural marks, with memories, with feelings, with doubts, and torn dreams that have not yet been destroyed, [...].

No fundo, eu vinha educando minha esperança enquanto procurava a razão de ser mais profunda de minha dor. [...] Desvelei o problema pela apreensão clara e lúcida de sua razão de ser. Fiz a arqueologia de minha dor (p. 30-31).
}

\footnotetext{
${ }^{1}$ The quotes are the author's free translations. 
JUNKER, Débora Barbosa Agra. The poetic-prophetic dimension of Freirean pedagogy to imagine another world possible.

Deep inside, I was educating my hope while also trying to find why my pain was so profound. [...] I unveiled the problem by clearly and lucidly grasping its "why." I carried out the archeology of my pain.

No fundo, é muito difícil viver no exílio [...] conviver com a saudade e educá-la também (p. 34).

Indeed, it is very difficult to live in exile [...] to live with the pain of longing and educate it, too.

O que aqui, porém, me preocupa é acentuar o quanto a fala popular e a escassez nela de esquinas arestosas que nos firam (p. 69).

What concerns me here, however, is to accentuate the degree to which popular speech bears the scarcity of edges that hurt us.

Ler um texto não é passear licenciosamente, pachorrentamente, sobre as palavras (p. 76).

Reading a text is not to walk licentiously, with parsimony, on the words.

Freire's careful use of language evokes in us a world full of meanings, implications, values, symbolic exchanges, emotional communications, social awareness while, at the same time, invites us to see ourselves as conscious beings in our becoming-in-the-world. For instance, in expression such as "corpo molhado de história" the invitation is not only to apprehend history. Freire - through his prose - is inviting us to have an aesthetic experience using all our senses by tasting and feeling in our body what means to have our bodies soaked, drenched, and dripping with history. The other expression "sonhos rasgados" immediately orient us to an embodied experience of seeing our utmost dreams shredded, as though they were paper, right in front of our eyes. For Freire, it does not suffice to express the frustration of an unfulfilled dream. He invites us into an imaginative experiment of seeing our dreams crushed, "torn to pieces." His chosen words have a fantastic power and capacity not only to speak in new ways but also to call us into a kind of action of sorts: to creatively respond to the activation of our imaginations. They are words pregnant with possibilities. These metaphors invite us into a keener perception - to see and feel the perils of existence with the eyes of our hearts. Aware of the power of imagination, Freire reminds us that "transforming the inequitable structures of society, implies the articulated exercise of imagining a less ugly, less cruel world. It implies imagining a world we dream of, a world that is not yet, one different from the world that is, and a world to which we need to give form" (FREIRE, 2004, p. 14). The same can be said regarding the prophetic dimension of his thoughts and writings, to which I turn next. 


\section{The Prophet's Utterances}

Freire's prophetic thinking has its roots in the Christian and Humanist heritage nurtured during his formative years. In his conversation with Myles Horton, he recalls how his parents would discuss their different perspectives on faith without imposing their view on each other while also encouraging their children to develop a consistency "between proclaiming the faith and having consistent behavior vis-à-vis this faith" (HORTON; FREIRE, 1990, p. 243). As a young adult, he experienced the significant historical-political-social moment in Brazil, which was marked by the dynamism of social movements that were challenging the colonial traces in the country. Such movements were also advocating for the radical transformation of Brazilian society through the so-called basic social reforms that aimed to provide resources and dignity to the most vulnerable. It was within this context that Freire began to articulate his educational philosophy stressing the importance of education for critical consciousness as he was aware of the social problems of his country while also motivated by his vision of human beings as well as his faith's imperative of loving one's neighbor. For Freire, the history of humanity is the starting point for his theological reflection. His religious convictions are grounded in a God who cares about human well-being and liberation and will become the core element of his pedagogical praxis.

The political, economic, and cultural circumstances that created a favorable environment for rethinking education began to impact the Church as well. Concerned with the problems plaguing the country, the Church started to rethink her role under these circumstances and began to experience a significant revitalization. Thus, for the first time in the history of Latin American Christianity, an autochthonous theological thought began to take shape. According to Carlos Alberto Torres, there is a significant resemblance between the Final Documents of Episcopal Conferences of Medellin produced by the Catholic Bishops and Freire's philosophy of education as exposed in his early books. Torres affirms that "Freire's thought is clearly evidenced in the document on education” issued by the Bishops (TORRES 1993, p. 122). Freire's pedagogical insights offered a methodological path to the emerging Catholic and Protestant theological thinking, known as Liberation Theology and its "preferential option for the poor." In Freire's view, Liberation Theology was fundamentally "a prophetic, utopian theology, full of hope" that emerged from the "hopeless situation" of occupied societies (FREIRE, 1985, p. 137). 
JUNKER, Débora Barbosa Agra. The poetic-prophetic dimension of Freirean pedagogy to imagine another world possible.

Although utilizing various sources to develop his humanist education-ranging from scholastic philosophy to existential phenomenology - Freire admits he did not feel comfortable speaking openly about his faith. However, he never abdicated his Christian vision guided by the values of the Gospel, especially the notion of a liberating God who empathizes with the oppressed people and rejects the oppressive forces and structures that try to dehumanize them. Consequently, his faith was a source of strength compelling him to work on behalf of the oppressed, as he declares, "when I went first to meet with workers and peasants in Recife's slums, to teach and to learn from them, I have to confess that I did it pushed by my Christian faith" (HORTON; FREIRE, 1990, p. 245).

For him, Christian faith was not an excuse to accept oppression passively, but a call to a transforming praxis that encompasses prophecy and hope. Hence, a faith that anchors itself in passivity and accommodation is an alienating faith that corroborates and promotes inequities. Fundamentally, it is a faith that contradicts the Christian message to love God and one's neighbors. Love, in this respect, is not an abstraction, but it materializes in concrete actions of solidarity and justice in the face of oppressive socio-economic-cultural circumstances. Freire also underscores the importance of having hope to achieve and sustain what he considers the ontological vocation of humankind: humanization. Through human capacity to hope, it is possible to imagine a world where everybody belongs. In this perspective he reminds us,

The matrix of hope is the same as the educability of human beings: the incompleteness of their being, which became conscious. It would be an aggressive contradiction if, unfinished and aware of the incompleteness, the human beings do not participate in an ongoing process of seeking hope. This process is education. But precisely because we find ourselves subjected to an endless number of constraints - obstacles difficult to overcome, dominant influences of fatalistic conceptions of history, the power of neoliberal ideology, whose perverse ethics is based on the logic of the market - never, perhaps, we have had more need to stress through the educational practices, the sense of hope needed today. Hence, among several fundamental practices of educators, whether liberal or conservative, it notes the following: change is difficult but possible (FREIRE, 2004, p. 100).

According to Freire's prophetic analysis — which implies the denouncement of oppression and announcement of a transformed world-he makes explicit his concern with the oppressive nature of institutional churches insisting that the task of Christians is to combat all forms of oppression. In his view, God is a dynamic God who works not on behalf of the powerful but for the liberation of the oppressed. Furthermore, in "A Letter to a Theology Student" he states, 
JUNKER, Débora Barbosa Agra. The poetic-prophetic dimension of Freirean pedagogy to imagine another world possible.

The word of God is inviting me to re-create the world, not for my brothers' domination, but for their liberation. [...] Listening to the word of God does not mean acting like empty vessels waiting to be filled with that word. [...] That is why I insist that a utopian and prophetic theology leads naturally to a cultural action for liberation and hence to conscientization (FREIRE, 1972, p. 2).

At his tenure as a consultant at the World Council of Churches in Geneva - WCC (19701980), he was able to better articulate his critique of the church, which, according to him, had forgotten its true role. In a selection of articles of Freire's lectures published by LADOC during 1970-1972, there are explicit references as to how he understands the role of Christians and the Church (FREIRE, 1972). Particularly in the texts Conscientizing as Way of Liberating, The Third World and Theology, and The Educational Role of the Church in Latin America, Freire draws from the Christian tradition to build upon themes such as hope, love, justice, freedom, and prophecy_denouncement/announcement - challenging Christians to embrace a more coherent position between their words and actions. For Freire, "having faith is not a problem; the problem is claiming to have it and, at the same time, contradicting it in action" (FREIRE, 1998, p. 104).

In the book The Politics of Education, Freire expands on his understanding of what means to act prophetically (FREIRE, 1985, p. 121-142). Consistent with his prophetic vision, he asserts that churches are not abstract entities, but institutions inserted in history, and as a result, they cannot afford to be neutral since neutrality means to support the status quo. Making use of a familiar expression in the Bible, he says: "washing one's hands" of the conflict between the powerful and the powerless does not mean to be neutral but to be on the side of the powerful" (FREIRE, 1985, p. 121). Also, he argues that the church needs to change its "aspirin practices" and the belief that through sermons, humanitarian work and charity, changes can be attained. He adverts, "In the last analysis the basic presupposition of such action is the illusion that the hearts of men and women can be transformed while the social structures that make those hearts 'sick' are left intact and unchanged" (FREIRE, 1985, p. 122). Accordingly, the radical transformation of the social structures requires a changed perspective which is not automatic or mechanic.

Evoking another Christian symbolism, he stresses that the church, and all men and women for that matter, need to undergo their own Easter process - which means to die to their myth of superiority, purity of soul, wisdom, and neutrality or to the myth of inferiority, impurity, and absolute ignorance - so that they can be born again, and be transformed. Thus, the Easter which results in the changing of consciousness must be existentially experienced because it is not mere 
JUNKER, Débora Barbosa Agra. The poetic-prophetic dimension of Freirean pedagogy to imagine another world possible.

commemorative rhetoric, but praxis. Freire recognizes, however, that this is not an effortless process since the necrophiliac - death-loving — is unable to accept the biophilic_life-lovingexperience of Easter. "It is only in the authenticity of historical praxis that Easter becomes the death that makes life possible" (FREIRE, 1985, p. 123). He goes on to say that the experience of rebirth is only possible at the side of the oppressed in the process of liberation, which points toward a process of conscientização. Such process of critical consciousness implies a dialectical unity between action and reflection-praxis - a reasonable attempt to reveal the reality that undoubtedly encompasses a political involvement to unveil the dream of a transformed reality. Freire says,

\begin{abstract}
Dreaming is not only a necessary political act, but it is also an integral part of the historic-social manner of being a person. It is part of human nature, which, within history, is in a permanent process of becoming. [...] Thus, I keep insisting, ever since Pedagogy of the Oppressed: there is no authentic utopia apart from the tension between the denunciation of a present becoming more and more intolerable, and the "annunciation," announcement, of a future to be created, built - politically, esthetically, and ethically - by us women and men. Utopia implies this denunciation and proclamation, but it does not permit the tension between the two to die away with production of the future previously announced (2007, p. 77$)$.
\end{abstract}

From a prophetic perspective, the dream of a society less ugly and less discriminatory cannot be attained passively. It implies the analysis of the social structures denouncing their unjust arrangements and announcing its radical transformation through a political praxis in the service of human liberation.

In 1997, shortly before his ultimate death, Freire was actively working on what would be his next book. Thanks to the diligent and loving work of Nita Freire, we have access to this collection of texts written with "joy and indignation." She affirms, "This book, perhaps more than others, is 'drenched,' as he might say, in his humanistic love and his political anger or indignation, which translated into his entire body of work, as he lived those feelings through his very existence" (FREIRE, 2004, p. xxxi). Writing with his poetic-prophetic style, Freire's description of that time seems to anticipate or prophesy, about the circumstances we find ourselves immersed today. He writes,

There is no possibility we could think of tomorrow, whether a nearer or more distant one, without finding ourselves in a permanent process of "emersion" from today, without being "drenched" in the time which we live, touched by its challenges, provoked by its problems, insecure before the insanity that announces disasters, taken by a just rage in light of profound injustices which express, in terrifying levels, the human 
capacity for ethical transgression. Also, there is no possibility of thinking of tomorrow without being encouraged by testimonies of gratuitous loving of life, which strengthen in us that so-needed and at times embattled hope (FREIRE, 2004, p. 103)

Drawing from his poetic-prophetic sensitivity, Freire asserts that reflecting on things that touch our existence is to prophesy because prophets are those who seek to understand the reality and instead of isolating themselves from the unbearable pressing circumstances, they become a presence in the world, reading the signs and speaking truth to the power. They fulfill the premise required from prophets "to denounce how we are living and announcing how we could live" (FREIRE, 2004, p. 105). The prophetic announcing, however, it not a fatalistic hunch or charade, but a form of intervention in the world bringing to light the yearnings that have been denied so that transformation can take place. And Freire summons such change through carefully crafting prophetic thoughts articulated in poetic language. For those of us who have been robbed of our right to be, poetic-prophetic articulations not only restore dimensions of our humanness-while working to dismantle the structures that oppress them-but also breathe back into our realities the presence of beauty. According to him, only utopians can be prophetic, reacting against a culture of silence without losing hope. Oppressors and reactionaries cannot be utopians because they cannot be prophetic and hopeful.

\section{Concluding thoughts}

The importance and influence of Freire's poetic-prophetic thinking cannot be underestimated in contemporary contexts where hate-filled rhetoric, anti-democratic speeches, and fundamentalist ideologies have disturbed the global landscape. Furthermore, one cannot dismiss the relevance of his critique to contemporary societies with the excuse that his educational philosophy is constructed on the premises of Christian values. Freire's poeticprophetic perspective empowers us to renounce an uncritical adherence to the legalist and fundamentalist interpretation of reality and abandon the palliative actions which do not change social structures. Being a prophetic voice on behalf of the poor, the marginalized, and the discriminated is a task that we must engage if we want to build another world where justice, beauty, equality, and democratic relations can thrive. In this context, we are called to read our reality with critical awareness, illuminated by pedagogies of indignation and hope. Indeed, today's prophets cannot accomplish their vocation unless they are invested in the remarkable 
labor of eliciting the process of critical consciousness, which implies the denouncement of all that is inhuman and the announcement of a transformed reality.

As Paulo Freire reminds us, the prophetic church must continuously move, always dying and reborn forever (FREIRE 1985, p. 139). However, it is not only the church called to overcome its deep colonial traits, but all of us, men and women, need to disentangle these bonds that imprison and blind us so that we can see reality as it really is. Freire's invitation is for us to make this Travessia, not by dissociating our mundanidade (worldliness) from our transcendentalidade (otherworldly) but living both in its fullness. Freire's work invites us to engage these processes of responsiveness and awareness by activating our imagination through poetic-prophetic language that draws deeply from the wells of our imaginations. If we dare to accept his invitation, we will be able to remake our history and forge a new world. Therefore, we will embody the challenge of living our lives poetically and prophetically until we see the world we hope for becoming tangible.

\section{References}

BRUEGGEMANN, Walter. The prophetic imagination. 2. ed. Minneapolis: Fortress, 2001.

FREIRE, Paulo. The politics of education: culture, power, and liberation. Massachusetts: Bergin \& Garvey, 1985.

FREIRE, Paulo. Pedagogia da esperança: um re-encontro com a pedagogia do oprimido. São Paulo: Paz \& Terra, 1994.

FREIRE, Paulo. Pedagogy of the heart. New York: Continuum, 1998.

FREIRE, Paulo. Pedagogy of indignation. Boulder: Paradigm Publishers, 2004.

FREIRE, Paulo. Pedagogy of hope: reliving pedagogy of the oppressed. New York: Continuum, 2007.

FREIRE, Paulo. A letter to a theology student. Washington, D.C.: LADOC, 1972. v. II.

HESCHEL, Abraham. The prophets: an introduction. New York: Harper \& Row, 1962. v. 1.

HESCHEL, Abraham. The prophets. New York: Harper \& Row, 1962. v. 2.

HORTON, Myles; FREIRE, Paulo. We make the road by walking: conversation on education and social change. Philadelphia: Temple University Press, 1990.

TORRES, Carlos Alberto. From the pedagogy of the oppressed to a Luta Continua. In: MCLAREN, Peter. Paulo Freire, a critical encounter. New York: Rutledge, 1993. 
JUNKER, Débora Barbosa Agra. The poetic-prophetic dimension of Freirean pedagogy to imagine another world possible.

Débora Barbosa Agra Junker

Cátedra Paulo Freire - Garrett Evangelical Theological Seminary | Assistant Professor of Christian Education / Founder and Director

Evanston | Illinois | EUA. Contato: debora.junker@ garrett.edu ORCID 0000-0003-3189-8100

Artigo recebido em: 3 jul. 2018 e aprovado em: 9 jul. 2018. 